\title{
The clinical relevance of microsatellite alterations in head and neck squamous cell carcinoma: a critical review
}

\author{
Harlinde De Schutter*, ${ }^{*}$, Marijke Spaepen ${ }^{2}$, William H Mc Bride ${ }^{3}$ and Sandra Nuyts ${ }^{1}$ \\ ${ }^{1}$ Department of Radiation Oncology, Lab of Experimental Radiotherapy, UH Gasthuisberg, Leuven, \\ Belgium; ${ }^{2}$ Department of Human Genetics, UH Gasthuisberg, Leuven, Belgium; ${ }^{3}$ Department of Radiation \\ Oncology, David Geffen School of Medicine at UCLA, University of California Los Angeles, Los Angeles, \\ California, USA
}

Triggered by the existing confusion in the field, the current paper aimed to review the current knowledge of both microsatellite instability (MSI) and loss of heterozygosity (LOH) detected by microsatellite markers in head and neck squamous cell carcinoma (HNSCC), and to provide the reader with an assessment of their prognostic and predictive value in this tumor type. For both MSI and LOH, various detection methods were included such as mono- and polynucleotidemarkers and gel- as well as automated analyses. Only studies based on PCR techniques with microsatellite markers were considered. Taking the methodological problems occurring in investigations with microsatellite markers into account, LOH seems to be more common than MSI in HNSCC. Although both types of microsatellite alterations have been correlated with clinicopathological features of this tumor type, only LOH seems to have a clear prognostic value. The predictive value of both MSI and LOH is debatable. More research has to be performed to clearly establish $\mathrm{LOH}$ detection as a translational application in the HNSCC field, aiming to predict response to treatments or outcome, and eventually to use as a therapeutic target.

European Journal of Human Genetics (2007) 15, 734-741; doi:10.1038/sj.ejhg.5201845; published online 2 May 2007

Keywords: head and neck squamous cell carcinoma; microsatellite instability; loss of heterozygosity

\section{Introduction}

Head and neck squamous cell carcinoma (HNSCC) is the sixth most common solid tumor worldwide, with an annual incidence of more than 500000. Traditional treatment of this tumor type is based on combinations of surgery, radiotherapy and chemotherapy with still a rather poor success rate for locally advanced disease. As a result, enormous efforts are currently being put into the search for new molecular markers and associated molecular treat-

*Correspondence: Dr H De Schutter, Lab of Experimental Radiotherapy, UH Gasthuisberg, CDG - 8th floor - box 815, Herestraat 49, 3000 Leuven, Belgium. Tel: + 32163462 95; Fax: + 32163469 01;

E-mail: harlinde.deschutter@uz.kuleuven.ac.be

Received 13 September 2006; revised 26 February 2007; accepted 4 April 2007; published online 2 May 2007 ment strategies that might stratify patients and individualize treatment options. With these aims in mind, microsatellite alterations such as microsatellite instability (MSI) and loss of heterozygosity (LOH) gained a lot of interest during the last decade.

The interest in MSI as possible tumor marker was greatly influenced by the marked presence and prognostic value of this phenomenon in Hereditary Non Polyposis Colon Cancer (HNPCC). ${ }^{1}$ MSI is also typically associated with Turcot's and Muir-Torre syndrome. ${ }^{2}$ However, the frequency and clinical value of MSI in other solid tumors including HNSCC differs widely, largely due to an obvious variance in used methods and criteria. ${ }^{2}$

Concerning LOH, different techniques have been developed to assess this type of alterations. The further 
report on $\mathrm{LOH}$ in this work will only refer to $\mathrm{LOH}$ detected with microsatellite markers. Problems of methodological variance trouble the reported frequencies, in alignment with MSI assessment. The prognostic and predictive value of this phenomenon varies along different tumor types (bladder, prostate, brain cancer). ${ }^{3-5}$ Although the potential of LOH as a molecular prognostic marker in HNSCC has gained confidence over the years, literature on this field stays confusing.

The aim of this paper was to review the current knowledge of microsatellite alterations, both MSI and LOH, in HNSCC and to provide the reader with an assessment of their prognostic and predictive value.

\section{What are MSI and LOH?}

Microsatellites are stretches of DNA in which a short motif (usually 1-5 nucleotides long) is repeated 5-100 times. Microsatellite regions are at high risk for variations in the number of repeats caused by slippage of the DNA polymerase during DNA replication. In normal cells, these errors get repaired by the mismatch repair system (MMR) involving proteins such as MLH1, MLH3, MSH2, MSH3, MSH6, PMS1 and PMS2. In tumors, defects in the MMR system may be present, so that variations in microsatellite regions are not repaired correctly, leading to definitive somatic changes with gain or loss of repeat units. MSI can thus indicate the presence of a defect MMR system. Interestingly, MMR deficiency can lead to carcinogenesis as a result of mutations in key genes, defining a so-called mutator phenotype. According to Field, MSI could serve as an indirect marker for the somatic mutations caused by the mutator phenotype. ${ }^{6}$ This mutator phenotype is an important carcinogenetic mechanism in HNPCC, which is associated with inherited MMR mutations. ${ }^{1}$

Genetic and epigenetic inactivation of the MMR pathway is however not a commonly event in solid tumor types other than HNPCC. Therefore, MSI in these other tumor types, if observed, may be due to factors other than defects in MMR genes such as malfunctioning of factors downstream of MMR components or in other systems that proofread DNA for replication errors. ${ }^{7}$ Although not clearly established, environmental factors such as oxygen radicals, lipid adducts, smoking or diet also could play a role in generating MSI. These exposures can act alone or in concert with defective DNA repair pathways. ${ }^{8}$

$\mathrm{LOH}$, in contrast, marks a suppressor phenotype that is characterized by wide variety in chromosomal numbers (aneuploidy) and extensive loss of genetic material. Even if nowadays most $\mathrm{LOH}$ investigations use comparitive genomic hybridization or single-nucleotide polymorphisms (SNPs) techniques, the presence of LOH can also be detected with the use of microsatellite markers. Accordingly, LOH can be recognized by loss of a genomic fragment, SNP or microsatellite allele in a tumor when compared with normal tissue. LOH is a common mechanism of inactivation of tumor suppressor genes (TSG) located in the neighborhood of the allelic marker that is being detected. TSG loss is normally confirmed by investigating gene deletion or mutation, silencing by DNA methylation or concurrent loss of protein expression. ${ }^{9}$

\section{Prevalence of MSI and LOH in HSNCC MSI}

In HNSCC, the reported frequencies of MSI vary widely but in general the incidence is low leaving any significance unclear. Table 1 that shows the published studies till now on MSI in HNSCC indicates that the incidence varies from $3^{21}$ to $88 \%{ }^{24}$ of MSI-H, largely depending on the number of patients, the loci and markers used, the patient age and detection methods.

In general, MSI in HNSCC seems to be a late event associated with tumor progression. Most studies show that invasive carcinomas manifest more MSI than precursor lesions, suggesting progressive accumulation of MSI during tumor development ${ }^{12,28}$ (Table 1). Furthermore, precursor lesions that show MSI are more prone to progress to HNSCC. ${ }^{19}$ Arguments against this vision arise from studies showing high MSI incidences in pre-malignant lesions and in young patients. ${ }^{20,24}$

Most studies report on a lack of MMR gene defects in HNSCC compared with HNPCC. ${ }^{14,21,24,29}$ This could either indicate a low incidence of MSI or a higher proportion of non-MMR MSI cases. In HNSCC, this could be caused by common carcinogens for this patient group, such as smoking. However, it could also mean that 'true' MSI in HNSCC does not exist - at least not in the way it does in HNPCC.

\section{LOH}

Numerous different techniques have been used to assess $\mathrm{LOH}$ alterations in HNSCC. Perhaps this is one reason why, although the potential of this molecular prognostic marker has gained confidence over the years, the literature in this field stays confusing. Table 2 lists the published studies on $\mathrm{LOH}$ detected with microsatellite markers in HNSCC.

Most suggest that the frequency of $\mathrm{LOH}$ is higher than of MSI, indicating that the suppressor phenotype could be more prevalent. ${ }^{11,12,36} \mathrm{LOH}$ and the spectrum of chromosomal loss progressively increases at each histopathological step from benign hyperplasia to dysplasia to carcinoma in situ to invasive cancer. ${ }^{19,33,53}$ Some primary and recurrent HNSCC originate from the same precursor lesion that contains genetically related features to the tumors, including $\mathrm{LOH}^{54}$

Overall, studies in HNSCC have shown that deletions at chromosome arms $3 p, 4 p, 8 p$ and $9 p$ represent early 
Table $1 \mathrm{MSI}$ in HNSCC

\begin{tabular}{|c|c|c|c|c|}
\hline Number of patients & Chromosomal arms or chromosomes & $\begin{array}{l}\text { Markers } \\
\text { (n) }\end{array}$ & MSI (\%) & Reference \\
\hline 40 & $3 p$ & 10 & $15 \% \mathrm{MSI}$ & Arai et $a l^{10}$ \\
\hline 56 primary, 23 resistant to chemo & $3 p, 9 p, 17 p, 8 p, 18 q$ & 22 & $\begin{array}{l}2 \% \mathrm{MSI}-\mathrm{H} \\
11 \% \mathrm{MSI}-\mathrm{L}\end{array}$ & Blons et $a l^{11}$ \\
\hline $\begin{array}{l}20 \text { (normal mucosa, dysplasia and } \\
\text { carcinoma of same patients) }\end{array}$ & $\begin{array}{l}3 p, 5 p, 5 q, 8 p, 9 p, 9 q, 11 q, 17 p \\
17 q, 18 p, 18 q\end{array}$ & 25 & $\begin{array}{l}15 \% \text { dysplasia } \mathrm{MSI}+ \\
30 \% \text { invasive ca } \mathrm{MSI}+\end{array}$ & $\begin{array}{l}\text { El Naggar } \\
\text { et } a l^{12}\end{array}$ \\
\hline 38 & $\begin{array}{l}1 p, 3 p, 3 q, 4 q, 5 p, 6 p, 7,8 p, 9 p \\
11 q, 13 q, 14 q, 17 p, 18 q\end{array}$ & 28 & $13 \% \mathrm{MSI}$ in one marker & Fiedler et $a l^{13}$ \\
\hline 23 & $\begin{array}{l}2 p, 1 p, 1 p t e r-1 q t e r, 3 p, 4 q, 5 q, 7 q \\
8 p t e r-8 q \text { ter }\end{array}$ & 9 & $\begin{array}{l}\text { Colon cancer history: } 25 \% \text { MSI- } \\
\text { H, } 25 \% \text { MSI-L } \\
\text { No colon cancer history: } 20 \% \\
\text { MSI-L, no MSI-H }\end{array}$ & Gleich et $a l^{15}$ \\
\hline 31 pre-malignant lesions & $\begin{array}{l}3 p 21,8 p 21-23,9 p 21(1 q, 3 q, 7 q \\
19 q, 20 q \text { as control markers) }\end{array}$ & 23 & $55 \% \mathrm{MSI}$ at $\geq 1$ locus & Partridge et $a l^{20}$ \\
\hline 67 & $1 p, 3 p, 3 q, 9 p, 13 q, 19 p$ & 20 & $\begin{array}{l}4 \% \text { MSI-L, } \\
3 \% \text { MSI-H }\end{array}$ & Piccinin et $a P^{21}$ \\
\hline 46 & 3p24-pter & 6 & $\begin{array}{l}16 \% \mathrm{MSI} \\
57 \% \mathrm{MSI} \text { or } \mathrm{LOH}\end{array}$ & Rowley et $a 1^{22}$ \\
\hline 41 & 18 & 10 & $\begin{array}{l}17 \% \mathrm{MSI} \\
56 \% \mathrm{MSI} \text { or } \mathrm{LOH}\end{array}$ & Rowley et $a 1^{23}$ \\
\hline $24 \leq 44$ years $33 \geq 45$ years & $\begin{array}{l}2 p, 3 p, 5 q, 8 p, 9 p, 13 q, 14 q \\
14 p t e r, 17 q, 21 q\end{array}$ & 16 & $\begin{array}{l}\leq 44 \text { years: } \\
100 \% \mathrm{MSI} \text { at } \geq 1 \text { loci } \\
88 \% \mathrm{MSI} \text { at } \geq 2 \text { loci } \\
\geq 45 \text { years: } \\
61 \% \mathrm{MSI} \text { at } \geq 1 \text { site } \\
36 \% \text { at } \geq 2 \text { sites }\end{array}$ & Wang et $a l^{24}$ \\
\hline
\end{tabular}

This table represents published studies on MSI showing the number of patients included, the chromosomal arms or chromosomes examined, the number of microsatellite markers used and the reported percentage of MSI.

genetic changes and that loss at $18 \mathrm{q}, 17 \mathrm{p}$ and 11qter is associated with neoplastic progression. ${ }^{33,34,36,45,48,55}$ Dysplastic regions in the head and neck region that show more LOH seem to be more at risk for neoplastic evolution. ${ }^{17,18,19,33}$

There are several reports that $\mathrm{LOH}$ is associated with more advanced stage and more aggressive HNSCC tumors, ${ }^{13,34,36,37,56}$ and specifically with nodal involvement. $^{32,44}$ Other authors describe very specific correlations such as a link between $\mathrm{LOH}$ at $17 \mathrm{p}$ and mitotic index, ${ }^{39}$ a connection of $\mathrm{LOH}$ at MLH1 with lower grade HNSCC, and LOH at CDKN2A with higher grade, ${ }^{9}$ or a preference of $\mathrm{LOH}$ in tumors originating from the pharynx. ${ }^{56}$ A correlation between $\mathrm{LOH}$ and other patient-related factors like age and race, was described in some studies. ${ }^{34,51}$

\section{Methodological issues}

The first critical point in MSI and LOH detection is microsatellite marker selection. The use of the Bethesda MSI reference $\operatorname{set}^{8}$ that was developed for HNPCC versus presumably more HNSCC-selective markers is hotly debated, as is the use of mononucleotide versus polynucleotide markers. ${ }^{17,57-59}$ However, most researchers currently accept that for MSI assessment, quasimonomorphic mononucleotide markers are suitable. For the detection of $\mathrm{LOH}$ with microsatellite markers, locus selection is dependent on the specific chromosomal region and possible associated TSG that the researchers reckon to be relevant.

Second cause for the observed variance in MSI and LOH reports lies in the use of different detection methods. The modern automatic fragment analysis procedures offer high throughput analysis and a more precise and quantitative 
Table $2 \mathrm{LOH}$ in HNSCC

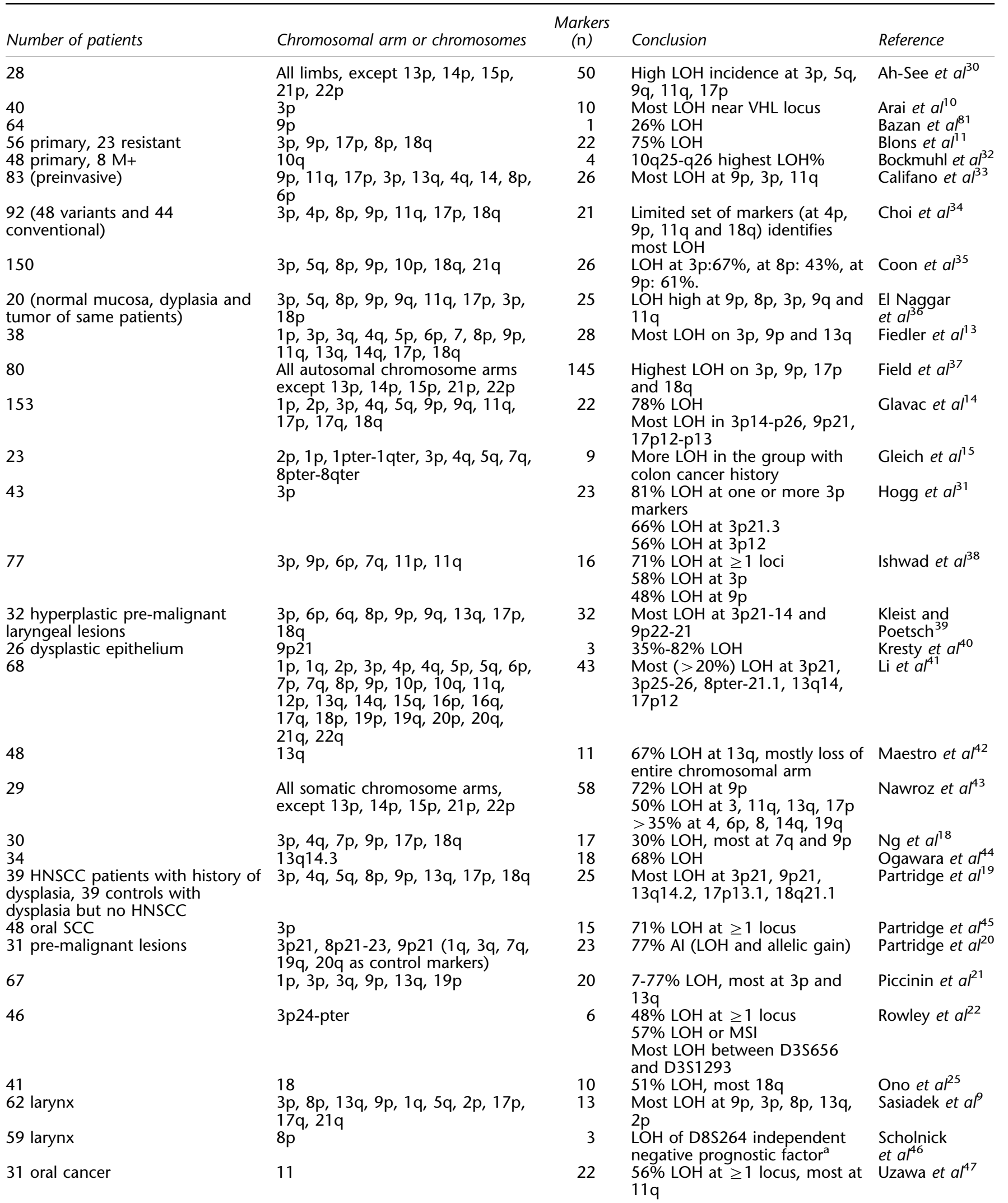


Table 2 (Continued)

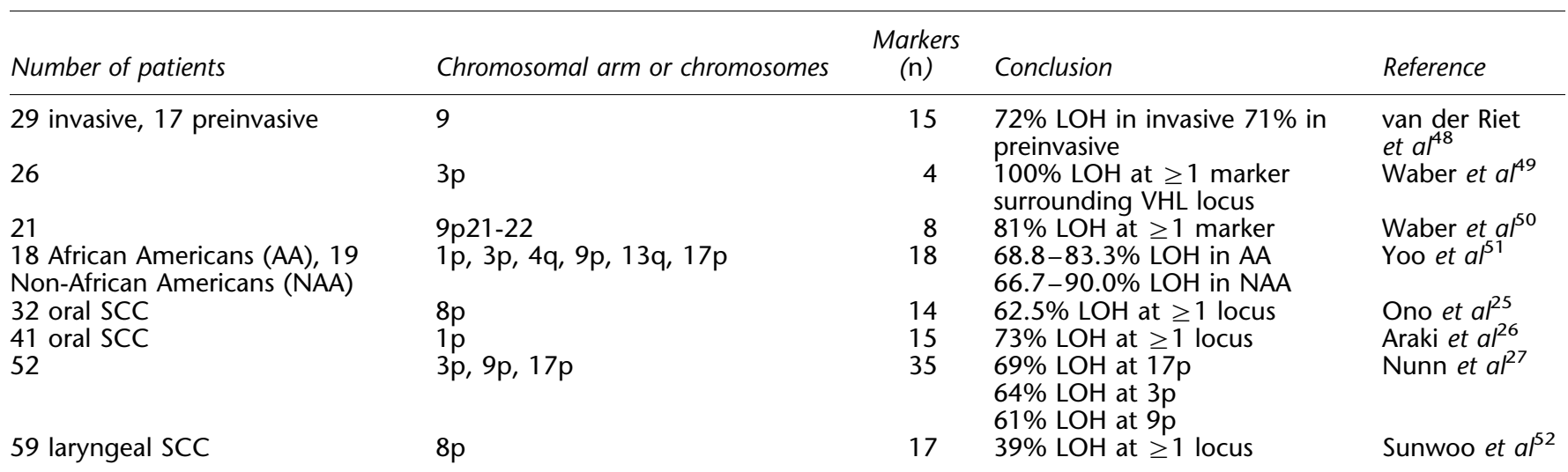

Al, allelic imbalance.

This table represents published studies on LOH showing the number of patients included, the chromosomal arms or chromosomes examined, the number of microsatellite markers used and the most important conclusions, respectively.

${ }^{\mathrm{a}} \mathrm{No}$ information on $\mathrm{LOH}$ prevalence in this study population.

assessment of MSI and $\mathrm{LOH}$ in comparison to the previously used gel electrophoresis methods. ${ }^{60-64}$ Although other points of discussion are the cutoff values to be used for $\mathrm{LOH}$ ratios (the ratio between the peak height ratios of both alleles of normal and paired tumor sample), 9,39,63,65 there is fairly general agreement that appropriate cutoffs are $>2$ or $<0.5$. A last issue is on the different types of MSI. Most investigators discern MSI-High (MSI-H, MSI in $\geq 30-40 \%$ of the markers tested) and MSI-Low (MSI-L, MSI in $<30-40 \%$ of the markers tested), ${ }^{8}$ although others call these Type I and $\mathrm{II}^{62}$ or Type B and A instability, ${ }^{66}$ respectively.

\section{Prognostic and predictive value of MSI and LOH in HNSCC MSI}

Prognostic value In HNSCC, the prognostic impact of MSI is not clear. ${ }^{2}$ Some studies showed that MSI positivity in pathologically negative surgical margins of HNSCC can independently predict local recurrence. ${ }^{67,68}$ Some authors found no correlation between MSI in HNSCC and survival, ${ }^{6}$ whereas others describe a better prognosis for MSI-positive patients, ${ }^{69}$ as recently also published for colorectal cancer. ${ }^{1}$ A possible explanation for the lack of prognostic value is the lack of statistical power in a lot of studies owing to the overall low prevalence of MSI in HNSCC, next to the previously mentioned difference in methodology.

Predictive value As MMR-proficient cells undergo a cytotoxic reaction after recognition of drug-induced adducts in DNA, MMR deficiency can theoretically impart resistance to cancer chemotherapy agents. Some mainly in vitro and animal work on different tumor types indeed suggested that MMR-deficient cells have a poorer response to cisplatin, carboplatin and methylating agents.,69-71
However, clinical studies in colorectal cancer, in which a relation between MSI and MMR deficiency is clearly established, have not shown a consistent predictive value of MSI. ${ }^{1,72}$ For ionizing radiation (IR), a link with MMR defects is unlikely, as IR mainly causes DNA strand breaks and repair of this damage does not involve the MMR system. Therefore, it is not surprising that no predictive value of MSI towards chemotherapy or radiotherapy has been found in HNSCC, a malignancy in which the occurrence of MMR deficiency is uncertain. ${ }^{11}$

\section{LOH}

Prognostic value In general, $\mathrm{LOH}$ at multiple loci is associated with a poor clinical course such as nodal invasion or high-grade disease. ${ }^{44,55}$ Furthermore, several studies have identified a negative prognostic role for LOH, ${ }^{18,37,41,73,74}$ even in multivariate analyses. ${ }^{34,35,46}$ This negative prognostic value is mostly connected to allelic loss at 3p, 8p, 11q, 13q, 17p and 18q. On the other hand, $\mathrm{LOH}$ at $9 \mathrm{p} 21$ seems to be an early event in carcinogenesis (like LOH at 3p) that has not consistently been connected with a poor prognosis, ${ }^{34,35,75}$ but along with LOH at $7 \mathrm{q} 31$ has been related to tumor recurrence. ${ }^{76,77}$ At the most common loci, the occurrence of $\mathrm{LOH}$ is suggested to be associated with loss of TSG: FHIT at $3 p, p 16^{\text {INK4A }}$ at $9 p, R b$ at $13 \mathrm{q}$ and so on. For all of these TSG, a prognostic role has been described in HNSCC. ${ }^{78-80}$

Predictive value One study showed that microsatellite alterations in a histopathologically negative surgical margin can predict local recurrence. ${ }^{68}$

$\mathrm{LOH}$ is a frequent mechanism of inactivation of TSG, which might be involved in resistance to chemotherapy. A study in HNSCC showed an association between LOH at $9 \mathrm{p}$ or $17 \mathrm{p}$ resistance to a chemotherapy regimen consisting of cisplatin and 5-fluorouracil, with an independent 
negative predictive role for LOH at the p53 locus on 17p. The authors concluded that p53 alterations could play a role in chemotherapy resistance in HNSCC. ${ }^{11}$

\section{Conclusion}

This review aimed to explore current knowledge about microsatellite alterations (MSI/LOH) in HNSCC. HNSCC typically evolves from normal epithelium through dysplasia, carcinoma in situ finally to the invasive carcinoma stage. During this tumorigenesis, cumulative genetic alterations including MSI and $\mathrm{LOH}$ occur.

In HNSCC, most recent research efforts have been put into the investigation of $\mathrm{LOH}$ at several chromosomal loci. These alterations, representing the suppressor phenotype, seem to be more common than MSI in HNSCC. Although both types of microsatellite alterations have been correlated with clinicopathological features of head and neck cancer, only LOH seems to have a clear prognostic value. The predictive value of both MSI and LOH towards surgery, radiotherapy and chemotherapy is debatable. Biggest challenges however remain in the methodological problems connected with these types of investigations.

We recently tried to determine the real MSI and $\mathrm{LOH}$ prevalence in HNSCC, using automatic fragment analysis as the preferred technique to assess MSI and $\mathrm{LOH}$, several panels of microsatellite markers in an attempt to compare their sensitivity, and strict cutoff values for LOH detection. This study resulted in a very low (around 1\%) percentage of MSI, suggesting that indeed the prevalence of MSI in HNSCC has been overestimated in literature, partly due to the use of non-optimal techniques (De Schutter et al, submitted). ${ }^{82}$ Based on this experience, a role for MSI as prognostic or predictive marker in this tumor type seems highly unlikely.

On the other hand, the detection of $\mathrm{LOH}$ with the use of microsatellite markers in HNSCC seems feasible and of clinical importance. As $\mathrm{LOH}$ at certain loci may be indicative for the loss of a TSG, therapeutic options would mainly be directed towards re-expression of the involved gene, which is the goal of several gene therapy trials. However, re-expression therapies are mainly experimental and still face a lot of difficulties.

More research has to be performed to establish clearly LOH detection as a translational application in the HNSCC field, aiming to predict response to treatments or outcome, and eventually to use as a therapeutic target.

\section{Acknowledgements}

Harlinde De Schutter is a research fellow of the 'Fonds voor Wetenschappelijk Onderzoek-Vlaanderen' (FWO). This work was supported by a grant from the 'Klinisch OnderzoeksFonds' (KOF). We thank Professor Gert Matthijs of the Center of Human Genetics, $\mathrm{UH}$ Gasthuisberg, for his kind assistance to the preparation of this paper.

\section{References}

1 Popat S, Hubner R, Houlston RS: Systematic review of microsatellite instability and colorectal cancer prognosis. J Clin Oncol 2005; 23: 609-618.

2 Lawes DA, SenGupta S, Boulos PB: The clinical importance and prognostic implications of microsatellite instability in sporadic cancer. Eur J Surg Oncol 2003; 29: 201-212.

3 Fornari D, Steven K, Hansen AB et al: Transitional cell bladder tumor: predicting recurrence and progression by analysis of microsatellite loss of heterozygosity in urine sediment and tumor tissue. Cancer Genet Cytogenet 2006; 167: 15-19.

4 Fromont G, Valeri A, Cher $\mathrm{M}$ et al: Allelic loss at 16q23.2 is associated with good prognosis in high grade prostate cancer. Prostate 2005; 65: 341-346.

5 Wemmert S, Ketter R, Rahnenfuhrer J et al: Patients with high-grade gliomas harboring deletions of chromosomes $9 \mathrm{p}$ and $10 \mathrm{q}$ benefit from temozolomide treatment. Neoplasia 2005; 7: $883-893$.

6 Field JK, Kiaris H, Howard P, Vaughan ED, Spandidos DA, Jones AS: Microsatellite instability in squamous cell carcinoma of the head and neck. Br J Cancer 1995; 71: 1065-1069.

7 Claij N, te RH: Microsatellite instability in human cancer: a prognostic marker for chemotherapy? Exp Cell Res 1999; 246: $1-10$.

8 Boland CR, Thibodeau SN, Hamilton SR et al: A National Cancer Institute Workshop on Microsatellite Instability for cancer detection and familial predisposition: development of international criteria for the determination of microsatellite instability in colorectal cancer. Cancer Res 1998; 58: 5248-5257.

9 Sasiadek MM, Stembalska-Kozlowska A, Smigiel R, Ramsey D, Kayademir T, Blin N: Impairment of MLH1 and CDKN2A in oncogenesis of laryngeal cancer. Br J Cancer 2004; 90: 1594-1599.

10 Arai K, Shibahara T, Yamamoto N, Noma H: The presence of candidate tumor suppressor gene loci at chromosome $3 p$ for oral squamous cell carcinomas. Oral Oncol 2002; 38: 763-771.

11 Blons $\mathrm{H}$, Cabelguenne A, Carnot $\mathrm{F}$ et al: Microsatellite analysis and response to chemotherapy in head-and-neck squamous-cell carcinoma. Int J Cancer 1999; 84: 410-415.

12 El Naggar AK, Hurr K, Huff V, Clayman GL, Luna MA, Batsakis JG: Microsatellite instability in preinvasive and invasive head and neck squamous carcinoma. Am J Pathol 1996; 148: 2067-2072.

13 Fiedler W, Hoppe C, Schimmel B et al: Molecular characterization of head and neck tumors by analysis of telomerase activity and a panel of microsatellite markers. Int J Mol Med 2002; 9: 417-423.

14 Glavac D, Volavsek M, Potocnik U, Ravnik-Glavac M, Gale N: Low microsatellite instability and high loss of heterozygosity rates indicate dominant role of the suppressor pathway in squamous cell carcinoma of head and neck and loss of heterozygosity of 11 14.3 correlates with tumor grade. Cancer Genet Cytogenet 2003; 146: $27-32$.

15 Gleich LL, Wang J, Gluckman JL, Fenoglio-Preiser CM: Microsatellite instability as a predictor of survival in head and neck cancer - is there a link with colon cancer? ORL J Otorhinolaryngol Relat Spec 2003; 65: 193-198.

16 Ishwad CS, Ferrell RE, Rossie KM et al: Microsatellite instability in oral cancer. Int J Cancer 1995; 64: 332-335.

17 Mao L, Lee DJ, Tockman MS, Erozan YS, Askin F, Sidransky D: Microsatellite alterations as clonal markers for the detection of human cancer. Proc Natl Acad Sci USA 1994; 91: 9871-9875.

$18 \mathrm{Ng}$ IO, Xiao L, Lam KY, Yuen PW, Ng M: Microsatellite alterations in squamous cell carcinoma of the head and neck - clustering of loss of heterozygosity in a distinct subset. Oral Oncol 2000; 36: 484-490.

19 Partridge M, Pateromichelakis S, Phillips E, Emilion GG, A'Hern RP, Langdon JD: A case-control study confirms that microsatellite assay can identify patients at risk of developing oral squamous cell carcinoma within a field of cancerization. Cancer Res 2000; 60: 3893-3898.

20 Partridge M, Emilion G, Pateromichelakis S, A'Hern R, Phillips E, Langdon J: Allelic imbalance at chromosomal loci implicated in 
the pathogenesis of oral precancer, cumulative loss and its relationship with progression to cancer. Oral Oncol 1998; 34: 77-83.

21 Piccinin S, Gasparotto D, Vukosavljevic T et al: Microsatellite instability in squamous cell carcinomas of the head and neck related to field cancerization phenomena. Br J Cancer 1998; 78: $1147-1151$.

22 Rowley H, Jones A, Spandidos D, Field J: Definition of a tumor suppressor gene locus on the short arm of chromosome 3 in squamous cell carcinoma of the head and neck by means of microsatellite markers. Arch Otolaryngol Head Neck Surg 1996; 122: 497-501.

23 Rowley H, Jones AS, Field JK: Chromosome 18: a possible site for a tumour suppressor gene deletion in squamous cell carcinoma of the head and neck. Clin Otolaryngol Allied Sci 1995; 20: 266-271.

24 Wang Y, Irish J, MacMillan C et al: High frequency of microsatellite instability in young patients with head-and-neck squamous-cell carcinoma: lack of involvement of the mismatch repair genes hMLH1 AND hMSH2. Int J Cancer 2001; 93: $353-360$.

25 Ono K, Uzawa K, Nakatsuru M et al: Down-regulation of FEZ1/ LZTS1 gene with frequent loss of heterozygosity in oral squamous cell carcinomas. Int J Oncol 2003; 23: 297-302.

26 Araki D, Uzawa K, Watanabe T et al: Frequent allelic losses on the short arm of chromosome 1 and decreased expression of the p73 gene at 1 p36.3 in squamous cell carcinoma of the oral cavity. Int $J$ Oncol 2002; 20: 355-360.

27 Nunn J, Scholes AG, Liloglou $\mathrm{T}$ et al: Fractional allele loss indicates distinct genetic populations in the development of squamous cell carcinoma of the head and neck (SCCHN). Carcinogenesis 1999; 20: 2219-2228.

28 Ha PK, Pilkington TA, Westra WH, Sciubba J, Sidransky D, Califano JA: Progression of microsatellite instability from premalignant lesions to tumors of the head and neck. Int J Cancer 2002; 102: 615-617.

29 Nunn J, Nagini S, Risk JM et al: Allelic imbalance at the DNA mismatch repair loci, hMSH2, hMLH1, hPMS1, hPMS2 and hMSH3, in squamous cell carcinoma of the head and neck. Oral Oncol 2003; 39: 115-129.

30 Ah-See KW, Cooke TG, Pickford IR, Soutar D, Balmain A: An allelotype of squamous carcinoma of the head and neck using microsatellite markers. Cancer Res 1994; 54: 1617-1621.

31 Hogg RP, Honorio S, Martinez A et al: Frequent 3p allele loss and epigenetic inactivation of the RASSF1A tumour suppressor gene from region 3p21.3 in head and neck squamous cell carcinoma. Eur J Cancer 2002; 38: 1585-1592.

32 Bockmuhl U, Petersen S, Schmidt S et al: Patterns of chromosomal alterations in metastasizing and nonmetastasizing primary head and neck carcinomas. Cancer Res 1997; 57: 5213-5216.

33 Califano J, van der P, Westra W et al: Genetic progression model for head and neck cancer: implications for field cancerization. Cancer Res 1996; 56: 2488-2492.

34 Choi HR, Roberts DB, Johnigan RH et al: Molecular and clinicopathologic comparisons of head and neck squamous carcinoma variants: common and distinctive features of biological significance. Am J Surg Pathol 2004; 28: 1299-1310.

35 Coon SW, Savera AT, Zarbo RJ et al: Prognostic implications of loss of heterozygosity at $8 \mathrm{p} 21$ and 9p21 in head and neck squamous cell carcinoma. Int J Cancer 2004; 111: 206-212.

36 El Naggar AK, Hurr K, Batsakis JG, Luna MA, Goepfert H, Huff V: Sequential loss of heterozygosity at microsatellite motifs in preinvasive and invasive head and neck squamous carcinoma. Cancer Res 1995; 55: 2656-2659.

37 Field JK, Kiaris H, Risk JM et al: Allelotype of squamous cell carcinoma of the head and neck: fractional allele loss correlates with survival. Br J Cancer 1995; 72: 1180-1188.

38 Ishwad CS, Ferrell RE, Rossie KN et al: Loss of heterozygosity of the short arm of chromosomes 3 and 9 in oral cancer. Int J Cancer 1996; 69: 1-4.
39 Kleist B, Poetsch M: Divergent patterns of allelic alterations in premalignant laryngeal lesions indicate differences in the impact of morphological grading characteristics. Oncology 2004; 67: $420-427$.

40 Kresty LA, Mallery SR, Knobloch TJ et al: Alterations of p16(INK4a) and p14(ARF) in patients with severe oral epithelial dysplasia. Cancer Res 2002; 62: 5295-5300.

41 Li X, Lee NK, Ye YW et al: Allelic loss at chromosomes 3p, 8p, 13q, and $17 \mathrm{p}$ associated with poor prognosis in head and neck cancer. J Natl Cancer Inst 1994; 86: 1524-1529.

42 Maestro R, Piccinin S, Doglioni C et al: Chromosome 13q deletion mapping in head and neck squamous cell carcinomas: identification of two distinct regions of preferential loss. Cancer Res 1996; 56: $1146-1150$

43 Nawroz H, van der RP, Hruban RH, Koch W, Ruppert JM, Sidransky D: Allelotype of head and neck squamous cell carcinoma. Cancer Res 1994; 54: 1152-1155.

44 Ogawara K, Miyakawa A, Shiba M et al: Allelic loss of chromosome 13q14.3 in human oral cancer: correlation with lymph node metastasis. Int J Cancer 1998; 79: 312-317.

45 Partridge M, Emilion G, Langdon JD: $\mathrm{LOH}$ at $3 p$ correlates with a poor survival in oral squamous cell carcinoma. Br J Cancer 1996; 73: $366-371$.

46 Scholnick SB, Haughey BH, Sunwoo JB et al: Chromosome 8 allelic loss and the outcome of patients with squamous cell carcinoma of the supraglottic larynx. J Natl Cancer Inst 1996; 88: $1676-1682$.

47 Uzawa K, Suzuki H, Komiya A et al: Evidence for two distinct tumor-suppressor gene loci on the long arm of chromosome 11 in human oral cancer. Int J Cancer 1996; 67: 510-514.

48 van der Riet $\mathrm{P}$, Nawroz $\mathrm{H}$, Hruban $\mathrm{RH}$ et al: Frequent loss of chromosome 9p21-22 early in head and neck cancer progression. Cancer Res 1994; 54: 1156-1158.

49 Waber PG, Lee NK, Nisen PD: Frequent allelic loss at chromosome arm $3 p$ is distinct from genetic alterations of the Von-Hippel Lindau tumor suppressor gene in head and neck cancer. Oncogene 1996; 12: $365-369$

50 Waber P, Dlugosz S, Cheng QC, Truelson J, Nisen PD: Genetic alterations of chromosome band 9p21-22 in head and neck cancer are not restricted to p16INK4a. Oncogene 1997; 15: $1699-1704$

51 Yoo GH, Nguyen NX, Du W et al: Microsatellite alterations in african americans with head and neck cancer. Laryngoscope 2004; 114: $1619-1624$.

52 Sunwoo JB, Holt MS, Radford DM, Deeker C, Scholnick SB: Evidence for multiple tumor suppressor genes on chromosome arm $8 \mathrm{p}$ in supraglottic laryngeal cancer. Genes Chromosomes Cancer 1996; 16: 164-169.

53 Califano J, Westra WH, Meininger G, Corio R, Koch WM, Sidransky D: Genetic progression and clonal relationship of recurrent premalignant head and neck lesions. Clin Cancer Res 2000; 6: 347-352.

54 Tabor MP, Brakenhoff RH, Ruijter-Schippers HJ, Kummer JA, Leemans CR, Braakhuis BJ: Genetically altered fields as origin of locally recurrent head and neck cancer: a retrospective study. Clin Cancer Res 2004; 10: 3607-3613.

55 Bockmuhl U, Schwendel A, Dietel M, Petersen I: Distinct patterns of chromosomal alterations in high- and low-grade head and neck squamous cell carcinomas. Cancer Res 1996; 56: $5325-5329$.

56 Ransom DT, Leonard JH, Kearsley JH et al: Loss of heterozygosity studies in squamous cell carcinomas of the head and neck. Head Neck 1996; 18: 248-253.

57 Buhard O, Cattaneo F, Wong YF et al: Multipopulation analysis of polymorphisms in five mononucleotide repeats used to determine the microsatellite instability status of human tumors. J Clin Oncol 2006; 24: 241-251.

58 Perucho M Correspondence re: C.R. Boland et al: A National Cancer Institute workshop on microsatellite instability for cancer detection and familial predisposition: development of 
international criteria for the determination of microsatellite instability in colorectal cancer. Cancer Res 1998, 58:5248-5257. Cancer Res 1999; 59: 249-256.

59 Umar A, Boland CR, Terdiman JP et al: Revised Bethesda Guidelines for hereditary nonpolyposis colorectal cancer (Lynch syndrome) and microsatellite instability. J Natl Cancer Inst 2004; 96: $261-268$.

60 Maehara Y, Oda S, Sugimachi K: The instability within: problems in current analyses of microsatellite instability. Mutat Res 2001; 461: 249-263.

61 Oda S, Oki E, Maehara Y, Sugimachi K: Precise assessment of microsatellite instability using high resolution fluorescent microsatellite analysis. Nucleic Acids Res 1997; 25: 3415-3420.

62 Oda S, Maehara Y, Sumiyoshi Y, Sugimachi K: Microsatellite instability in cancer: what problems remain unanswered? Surgery 2002; 131: S55-S62.

63 Skotheim RI, Diep CB, Kraggerud SM, Jakobsen KS, Lothe RA: Evaluation of loss of heterozygosity/allelic imbalance scoring in tumor DNA. Cancer Genet Cytogenet 2001; 127: 64-70.

64 Deschoolmeester V, Baay M, Wuyts W et al: Comparison of three commonly used PCR-based techniques to analyze MSI status in sporadic colorectal cancer. J Clin Lab Anal 2006; 20: $52-61$.

65 Jou YS, Lee CS, Chang YH et al: Clustering of minimal deleted regions reveals distinct genetic pathways of human hepatocellular carcinoma. Cancer Res 2004; 64: 3030-3036.

66 Oda S, Maehara Y, Ikeda Y et al: Two modes of microsatellite instability in human cancer: differential connection of defective DNA mismatch repair to dinucleotide repeat instability. Nucleic Acids Res 2005; 33: 1628-1636.

67 Temam S, Casiraghi O, Lahaye JB et al: Tetranucleotide microsatellite instability in surgical margins for prediction of local recurrence of head and neck squamous cell carcinoma. Clin Cancer Res 2004; 10: 4022-4028.

68 Sardi I, Franchi A, Ferriero G et al: Prediction of recurrence by microsatellite analysis in head and neck cancer. Genes Chromosomes Cancer 2000; 29: 201-206.

69 Berry SE, Kinsella TJ: Targeting DNA mismatch repair for radiosensitization. Semin Radiat Oncol 2001; 11: 300-315.

70 Papouli E, Cejka P, Jiricny J: Dependence of the cytotoxicity of DNA-damaging agents on the mismatch repair status of human cells. Cancer Res 2004; 64: 3391-3394.
71 Maier S, Dahlstroem C, Haefliger C, Plum A, Piepenbrock C: Identifying DNA methylation biomarkers of cancer drug response. Am I Pharmacogenomics 2005; 5: 223-232.

72 Ribic CM, Sargent DJ, Moore MJ et al: Tumor microsatelliteinstability status as a predictor of benefit from fluorouracil-based adjuvant chemotherapy for colon cancer. N Engl J Med 2003; 349: 247-257.

73 Gleich LL, Li YQ, Wang X, Stambrook PJ, Gluckman JL: Variable genetic alterations and survival in head and neck cancer Arch Otolaryngol Head Neck Surg 1999; 125: 949-952.

74 Yamamoto N, Mizoe J, Numasawa H, Tsujii H, Shibahara T, Noma $\mathrm{H}$ : Allelic loss on chromosomes 2q, 3p and 21q: possibly a poor prognostic factor in oral squamous cell carcinoma. Oral Oncol 2003; 39: 796-805.

75 Bockmuhl U, Schluns K, Kuchler I, Petersen S, Petersen I: Genetic imbalances with impact on survival in head and neck cancer patients. Am J Pathol 2000; 157: 369-375.

76 Matsuura K, Shiga K, Yokoyama J, Saijo S, Miyagi T, Takasaka T: Loss of heterozygosity of chromosome 9p21 and $7 \mathrm{q} 31$ is correlated with high incidence of recurrent tumor in head and neck squamous cell carcinoma. Anticancer Res 1998; 18: 453-458.

77 Lydiatt WM, Davidson BJ, Schantz SP, Caruana S, Chaganti RS: 9 p21 deletion correlates with recurrence in head and neck cancer. Head Neck 1998; 20: 113-118.

78 Guerin LA, Hoffman HT, Zimmerman MB, Robinson RA: Decreased fragile histidine triad gene protein expression is associated with worse prognosis in oral squamous carcinoma. Arch Pathol Lab Med 2006; 130: 158-164.

79 Thomas GR, Nadiminti H, Regalado J: Molecular predictors of clinical outcome in patients with head and neck squamous cell carcinoma. Int J Exp Pathol 2005; 86: 347-363.

80 Soni S, Kaur J, Kumar A et al: Alterations of rb pathway components are frequent events in patients with oral epithelial dysplasia and predict clinical outcome in patients with squamous cell carcinoma. Oncology 2005; 68: 314-325.

81 Bazan V, Zanna I, Migliavacca M et al: Prognostic significance of p16INK4a alterations and 9p21 loss of heterozygosity in locally advanced laryngeal squamous cell carcinoma. J Cell Physiol 2002 192: 286-293.

82 De Schutter H, Spaepen M, Van Opstal S et al: Evaluation of microsatellite alterations in head and neck squamous cell carcinoma: is a tumor-specific panel indicated? submitted. 